\title{
Growth Performance, Length-Weight Relationship, Body Condition and Carcass Composition of Cyprinus carpio Fed with Poultry Dropping Incorporated Diets
}

\author{
R.S. Chauhan \\ Department of Aquaculture, College of Fisheries, \\ G. B. Pant University of Agriculture and Technology, Pantnagar- 263145, (U. K.) India
}

\begin{abstract}
Fifty fingerlings of common carp, Cyprinus carpio were stocked in each of four rectangular tanks. The formulated fish feed comprised of deoiled groundnut cake, rice polish, poultry dropping and vitamin-mineral feed supplement. The fishes in the tank T1 were fed with control diet D1 (0\% poultry dropping) and the fishes in tanks T2, T3 and T4 were fed with test diets D2 (10\% poultry dropping), D3 (15\% poultry dropping) and D4 (20\% poultry dropping), respectively. All diets contained around $30 \%$ protein. The fishes were fed @ 5\% of total body weight/day in two equal installments, one in the forenoon and other in late afternoon. Fishes were sampled fortnightly. Water quality parameters were monitored regularly. Highest specific growth rate (0.26\%/day) was recorded in tank $T 2$ where fishes were fed with $10 \%$ poultry dropping incorporated diet. The experimental fishes recorded the value of exponent ' $n$ ' in the range of 3.37 to 3.57, coefficient of correlation ' $r$ ' in the range of 0.9938 to 0.9987 and coefficient of determination ' $r 2$ ' from 0.9876 to 0.9974 . More than 98\% of experimental fishes departed from cube law of length-weight relationship towards higher side. The Condition Factor ' $K$ ' from 1.94 to 2.0 of experimental fishes indicated the well being and good condition of fishes. The analysis of muscle composition of fishes revealed that the protein content in muscle increased with the increasing amount of incorporated poultry dropping in fish feed.
\end{abstract}

Keywords: Specific growth rate, Condition factor, Formulated feed, Isometric growth.

\section{Introduction}

The success of composite culture of carps rests upon suitable species, good quality seed and appropriate supplementary feed. Expenditure on artificial feed alone accounts for over $40-45 \%$ of the total operational cost in semi intensive culture of carps. Chicken dropping has feed and fertilizer value. The increase in intensive rearing of poultry has resulted in considerable production of poultry dropping. The estimated 2010 world flock was over 18 billion birds with a yearly manure output of 22 million tones (FAO 2010). Recently increased attention has been paid to the use of it as a fertilizer and feedstuff for animals. Dried poultry dropping is good source of protein and minerals. Dried poultry manure contains sufficient levels of digestible energy, crude fibre, crude protein, crude fat, cobalt and iodine (Ghaly and MacDonald, 2012). Sharma et al., (1987) studied the biological performance of some organic and inorganic feeds on the common carp fingerlings growing under sub mountain region of Himachal Pradesh. Devaraj et al., (1988) tried poultry dropping based feed prepared by using $50 \%$ dried poultry faecal matter, $25 \%$ rice bran and $25 \%$ groundnut cake to compare the efficiency of poultry dropping based feed against conventional feed under composite fish culture system stocked with fingerlings of catla, rohu, mrigal and common carp. The condition factor in different cyprinids has been worked out by Pathak (1975), Pathani and Das (1980) 
and Yousuf and Pandit (1989). In the present study an attempt has been made to incorporate poultry dropping into formulated feed for common carp, Cyprinus carpio, raised in mildly flowing water condition, and to analyze the health status of fish fed with poultry dropping based artificial diets.

\section{Materials and Methods}

The study was carried out in four outdoor cemented rectangular tanks of the size of $8.0 \times 1.25 \times 0.85 \mathrm{~m}$. The water depth of $0.70 \mathrm{~m}$ was maintained throughout the study period (150 days). The flow of 25 I water/minute was maintained in all the tanks during 6.00 to 10.00 am, 12.00 noon to $3.00 \mathrm{pm}$ and 5.00 to $9.00 \mathrm{pm}$ daily. The first tank $\left(T_{1}\right)$ was used as control while other three $\left(T_{2}, T_{3}\right.$ and $\left.T_{4}\right)$ were used for different formulated test diets. Each tank was stocked with 50 numbers of measured and weighed fingerlings of common carp, Cyprinus carpio. Water temperature, $\mathrm{pH}$ and dissolved oxygen in tank water were regularly recorded and monitored. The experimental ponds were drained, cleaned and washed with lime water every fortnight to get rid of algal growth and microbes in tanks.

The artificial feed comprised of deoiled groundnut cake, rice polish, poultry dropping/ excreta and commercial mineral-vitamin feed supplement. The proximate analysis of feed ingredients and test diets was carried out as per procedure of AOAC (2000). Dried poultry excreta was incorporated into fish diets at the rate of $0 \%\left(D_{1}\right.$ control diet), $10 \%\left(D_{2}\right), 15 \%$ $\left(D_{3}\right)$ and $20 \%\left(D_{4}\right)$. The pelletized experimental diets were fed to fishes @ 5\% of fish body weight/day. The feed was given twice a day in two equal installments, one in forenoon around $9 \mathrm{AM}$ and the other during afternoon around 4 PM. Sampling of fish for growth and health monitoring was done at fortnightly intervals. Specific growth rate (SGR) of fish was assessed by the formula-

SGR $=$ In final weight - In initial weight $X 100$

$$
\text { Time (in days) }
$$

The length weight relationship of the experimental fishes is worked out as per cube law given by Le Cren (1951) as below-

$$
\mathrm{W}=\mathrm{CL}^{3}
$$

Where,

$$
\begin{aligned}
& W=\text { weight of fish in } \mathrm{g} \\
& L=\text { length of fish in } \mathrm{cm} \\
& C=\text { constant factor }
\end{aligned}
$$

The logarithmic transformation of above formula is-

$$
\log W=\log a+n \log L
$$

The condition factor $(\mathrm{K})$ of the fishes is calculated as per formula given below-

$$
\mathrm{K}=\frac{\mathrm{W}}{\mathrm{L}^{3}} \times 100
$$

Where,

$$
\begin{gathered}
W=\text { weight of fish }(\mathrm{g}) \\
\mathrm{L}=\text { length of fish }(\mathrm{cm})
\end{gathered}
$$

Fish muscles were analyzed for proximate composition as per procedure of AOAC (2000).

\section{Results and Discussion}

\section{Physico-chemical profile of water}

The profile of water temperature, $\mathrm{pH}$ and dissolved oxygen in experimented ponds has been presented in Fig 1. The water temperature during study period ranged between 16.0 and $21.2^{\circ} \mathrm{C}$. The $\mathrm{pH}$ of water in experimental tanks remained slightly or mildly alkaline throughout the experimental period barring four weeks when $\mathrm{pH}$ went little below 7.0. Amount of dissolved oxygen in water remained sufficiently above normal limit of $5 \mathrm{mg} / \mathrm{l}$, as suggested by Chauhan (2001). The analysis of variance revealed that differences in water temperature, $\mathrm{pH}$ and dissolved oxygen in four experimental tanks were not significant.

\section{Feed composition}

The composition of feeds used and proximate analysis of control and test diets have been presented in Tables 1 and 2, respectively. Authors like Devaraj et al., (1988), Jantrarotai and Boonman (1996), Abdelghany et al., 



Fig. 1. Pattern of variation of water temperature, $\mathrm{pH}$ and dissolved oxygen in experimental tanks $\mathrm{T}_{1}-\mathrm{T}_{4}$.

(1997), Saha and Ray (1998) and Nwanna (2002) substituted poultry waste in the form of litter, manure or dropping at the rates ranging from 10 to $50 \%$ in formulated feeds for different freshwater fishes including common carp. The crude protein content in poultry dropping was $24.2 \%$ (dry matter basis) which is much higher than rice polish (13.2\%). Obasa et al., (2009) sundried poultry manure for use as fish feed of African catfish (Clarias gariepinus) and reported 
Table 1 Composition of feed used in experimental tanks.

\begin{tabular}{|l|c|c|c|c|}
\hline Ingredients & Control diet $\left(\mathbf{D}_{\mathbf{1}}\right)$ & Test diet I $\left(\mathbf{D}_{\mathbf{2}}\right)$ & Test diet II $\left(\mathbf{D}_{3}\right)$ & Test diet III $\left(\mathbf{D}_{\mathbf{4}}\right)$ \\
\hline Deoiled groundnut cake & 56.55 & 53.02 & 51.26 & 49.49 \\
\hline Rice polish & 37.45 & 30.98 & 27.74 & 24.51 \\
\hline Poultry dropping & 0.00 & 10.00 & 15.00 & 20.00 \\
\hline Starch & 5.00 & 5.00 & 5.00 & 5.00 \\
\hline Mineral vitamin mixture & 1.00 & 1.00 & 1.00 & 1.00 \\
\hline Total & 100.00 & 100.00 & 100.00 & 100.00 \\
\hline
\end{tabular}

Table 2 Proximate analysis of the control and test diets fed to common carp.

\begin{tabular}{|l|c|c|c|c|}
\hline Content & $\mathbf{D}_{1}$ & $\mathbf{D}_{2}$ & $\mathbf{D}_{3}$ & $\mathbf{D}_{4}$ \\
\hline Crude protein (\%) & 29.97 & 29.99 & 30.10 & 30.15 \\
\hline Lipid (\%) & 5.84 & 5.87 & 6.02 & 5.92 \\
\hline Moisture (\%) & 6.57 & 10.54 & 11.03 & 11.98 \\
\hline
\end{tabular}

Table 3 Details of growth, harvesting and production of Cyprinus carpio in experimental Tanks.

\begin{tabular}{|l|r|r|r|r|}
\hline \multirow{2}{*}{ Details } & \multicolumn{4}{|c|}{ Tank } \\
\cline { 2 - 5 } & \multicolumn{1}{|c|}{$\mathrm{T}_{1}$} & \multicolumn{1}{c|}{$\mathrm{T}_{2}$} & \multicolumn{1}{c|}{$\mathrm{T}_{3}$} & \multicolumn{1}{c|}{$\mathrm{T}_{4}$} \\
\hline No. of fish stocked & 50.00 & 50.00 & 50.00 & 50.00 \\
\hline No. of fish harvested & 50.00 & 50.00 & 50.00 & 50.00 \\
\hline Survival (\%) & 100.00 & 100.00 & 100.00 & 100.00 \\
\hline Initial average weight (g) & 9.20 & 8.90 & 9.00 & 9.10 \\
\hline Final average weight (g) & 20.40 & 21.70 & 19.80 & 18.90 \\
\hline Total weight stocked (g) & 460.00 & 445.00 & 450.00 & 455.00 \\
\hline Total weight harvested (g) & 1020.00 & 1085.00 & 990.00 & 945.00 \\
\hline Gross production in tank (g) & 560.00 & 640.00 & 540.00 & 490.00 \\
\hline Specific Growth Rate (\%/day) & 0.23 & 0.26 & 0.23 & 0.21 \\
\hline
\end{tabular}

a protein content of $28.6 \%$. The crude protein content in experimental diets made for present study was near to $30 \%$ (29.97 - 30.15\%). The protein contents in poultry manure meal based diets prepared by Abdelghany et al., (1997) fed to blue tilapia, Oreochromis aureus, ranged from 29.91-30.14\%. Saha and Ray (1998) prepared poultry litter based test diets having 33.30-35.95\% crude protein for rohu (Labeo rohita) fingerlings.

\section{Growth and Production}

The data on survival, growth and production has been included in Table 3 . The highest specific growth rate was recorded in Tank $2\left(\mathrm{~T}_{2}\right)$ where the fishes were fed with the diet containing $10 \%$ poultry dropping in it. The differences in the harvested weights from different tanks were significant (Table 4). It is clear from the results that the growth rate decreased at 
Table 4 Analysis of variance (ANOVA) of weight at the time of harvesting of common carp from experimental tanks.

\begin{tabular}{|c|c|c|c|c|}
\hline $\begin{array}{c}\text { Source of } \\
\text { variation }\end{array}$ & df & ss & Ms & F-value \\
\hline Treatment & 3.00 & 207.00 & 69.00 & $3.1197 \mathrm{~s}$ \\
\hline Error & 196.00 & 4335.00 & 22.1173 & \\
\hline Total & 199.00 & 4542.00 & & \\
\hline
\end{tabular}

higher level of incorporation of poultry dropping in test diets. Abdelghany et al., (1997) incorporated poultry manure up to $20 \%$ to replace soybean meal from fish feed for blue tilapia. Saha and Ray (1998) recorded best specific growth rate in Labeo rohita fed with $20 \%$ poultry litter incorporated diet than the control one. It can be inferred from the results of present study that $10 \%$ dried poultry dropping can be incorporated as an ingredient in feed for common carp without affecting growth rate and survival of the fish.

\section{Length-weight Relationship}

The length-weight relationship was computed from data collected throughout the study period. The equations obtained are shown in Table 5. The values of regression coefficient ' $n$ ' (3.37 to 3.57) are in agreement with the studies of Otubusin (1990), Sarkar et al.,(1998) and Mitra et al.,(2005) who recorded the values of ' $n$ ' from 2.53 to 3.41. Ebanaser and Jayaprakas (2005) recorded the value of ' $n$ ' around 3 in Channa micropeltis. The value of ' $n$ ' exponent significantly greater than 3 or less than 3 denoted that the fish did not maintain the isometric pattern of growth. This means that if the exponent is less than 3 , the species becomes lighter for its length as it grows larger and if greater than 3 , the species becomes heavier for its length as it grows longer. In the present study, common carp recorded the value of ' $n$ ' ranging from 3.37 to 3.57 in all experimental tanks i.e. more than 3 . Thus, the results of the present study are in conformity with the views of Le Cren (1951) and Chauhan (1987) that as the fishes normally do not retain the same shape or body outline throughout their lifespan and specific gravity of tissues may not remain constant, the actual relationship may depart significantly from the cube law. The perusal of coefficients of correlation and determination revealed that more than $98 \%$ of the experimental fishes departed from the cube law lengthweight relationship towards higher side.

\section{Condition Factor}

The values of condition factor ' $K$ ' for the fishes stocked in experimental tanks are listed in Table 6. Various workers have calculated the Ponderal Index or condition factor of different fishes viz. 0.73-0.95 in Tor putitora (Pathani and Das, 1980), 1.03-1.31 in Salmo trutta fario (Kumar et al., 1979), 0.96-1.03 in Oreochromis mossambicus (Shendge, 2005) and 0.85-1.10 in Gadusia chapra (Masud and Singh, 2011). Kumar et al., (1979) concluded that a fish recording the value of condition factor as about 1.0 is considered to be of its average weight. This factor is indicator of the robustness or well being of fish. The values recorded in the present study are in range

Table 5 Length-weight relationship of common carp reared in experimental tanks.

\begin{tabular}{|c|c|c|c|}
\hline Tank & Logarithmic equations & Correlation Coefficient $(\mathbf{r})$ & Coefficient of Determination $\left(\mathbf{r}^{2}\right)$ \\
\hline$T_{1}$ & $\log W=-5.1913+3.5208 \log \mathrm{L}$ & 0.9987 & 0.9974 \\
\hline$T_{2}$ & $\log W=-5.2877+3.5708 \log \mathrm{L}$ & 0.9978 & 0.9956 \\
\hline$T_{3}$ & $\log W=-5.3104+3.5609 \log \mathrm{L}$ & 0.9979 & 0.9958 \\
\hline$T_{4}$ & $\log W=-4.8660+3.3730 \log \mathrm{L}$ & 0.9938 & 0.9876 \\
\hline
\end{tabular}


Table 6 Condition factor ' $\mathrm{K}$ ' of common carp in experimental tanks.

\begin{tabular}{|c|c|}
\hline Tank No. & Value of ' $K$ ' \\
\hline$T_{1}$ & 1.99 \\
\hline$T_{2}$ & 2.00 \\
\hline$T_{3}$ & 1.95 \\
\hline$T_{4}$ & 1.94 \\
\hline
\end{tabular}

Table 7 Carcass composition of common carp fed with control and poultry dropping incorporated test diets.

\begin{tabular}{|c|c|c|c|c|}
\hline \multirow{2}{*}{ Content } & \multicolumn{4}{|c|}{ Pond/Diet } \\
\cline { 2 - 5 } & $\mathrm{T}_{1} / \mathrm{D}_{1}$ & $\mathrm{~T}_{2} / \mathrm{D}_{2}$ & $\mathrm{~T}_{3} / \mathrm{D}_{3}$ & $\mathrm{~T}_{4} / \mathrm{D}_{4}$ \\
\hline Protein (\%) & 45.00 & 46.25 & 47.50 & 46.86 \\
\hline Lipid (\%) & 11.50 & 11.68 & 12.75 & 12.13 \\
\hline
\end{tabular}

from 1.94 to 2.0 which shows the well being of fishes raised on poultry dropping incorporated fish diets.

\section{Carcass Composition}

The analysis of body muscles of the experimental fishes has been presented in Table 7. Incorporation of poultry dropping in test diets increased protein as well as lipid content in the body muscles. No clear effect of poultry manure meal in fish diet on body composition of blue tilapia (Abdalghany et al., 1997) and poultry layer waste in fish diet on body composition of hybrid catfish (Jantrarotai and Boonman, 1996) have been reported. The results of the present study are in conformity with Saha and Ray (1998) who found the protein and lipid in the muscle of Labeo rohita to be increasing in the dietary treatments pertaining to incorporation of poultry litter in fish diets.

\section{References}

Abdelghany, A. E., Sayad, S. H., Abdul-Aziz and Shalaby, A. S. (1997). Partial replacement of soybean meal with poultry manure meal in diets for blue tilapia (Oreochromis aureus). J. Aqua.Trop., 12, 275-288.
AOAC. (2000). Official Methods of Analysis. Association of Official Agricultural Chemists, $17^{\text {th }}$ edition, Gaithersburg, MD, USA.

Chauhan, R. S. (1987). Food, parasites and length-weight relationship of a hill-stream fish, Schizothorax plagiostomus (Heckel). Ind. J. Anim. Res., 21, 93-96.

Chauhan, R. S. (2001). Status of composite culture of carps at three management levels in Tarai region of Uttaranchal, pp 11-14. In Singh, U. P., Chauhan, R. S. and Sharma, A. P. (eds.), Proceedings of the National Symposium on Fish Health Management and Sustainable Aquaculture.1-2 November, 2000; College of Fisheries, Pantnagar.

Devaraj, K.V, Shivanandamurthy, N. S. and Keshavappa, G. Y. (1988). Relative efficiency of poultry dropping based feed and conventional feed in composite fish culture. Mysore J. Agri. Sci., 22, 384-387.

Ebanasar, J. and Jayaprakas, V. (2005). Length-weight relationship of Channa micropeltes (Cuvier) from Pechipparai reservoir, Tamil Nadu. J. Inland Fish. Soc. India, 37, 60-63.

FAO (2010). Agricultural Handbook : Poultry Meat and Eggs. FAO Investment Centre Division, Rome, Italy.

Ghaly, A. E. and MacDonald, K. N. (2012). Drying of poultry manure for use as animal feed. Am. J. Agri. Biol. Sci., 7, 239-254.

Jantrarotai, W. and Boonman, C. (1996). Use of dried layer waste in diets for hybrid catfish Clarias macrocephalus x C. gariepinus. Prog. Fish Culturist, 58, 273-276.

Kumar, K., Sehgal, K. L. and Sundar, S. (1987). Lengthweight relationship and ponderal index of brown trout, Salmo trutta fario (Linn.) catches in the streams of Kashmir. J. Inland Fish. Soc. India, 11, 56-61.

Le Cren, E. D. (1951). The Length weight relationship and seasonal cycle in gonad weight and condition in the perch (Perca fluviatilis). J. Anim. Ecol., 20, 201-219.

Masud, S. and Singh, K.P. (2011. Length-weight relationship and condition factor of Gadusia chapra (Ham.) from river Yamuna. J. Inl. Fish. Soc. India, $43,45-50$

Mitra, K., Suresh, V. R., Vinci, G. K. and Naskar B. (2005). Length-weight relation, reproductive characters and condition of Puntius sophore (Hamilton) from a floodplain wetland in West Bengal. J. Inl. Fish. Soc. India, 37, 16-22.

Nwanna, L. C. (2002). Performance of hybrid clarid catfish fingerlings (Clarias gariepinus $x$ Heterobranchus bidorsalis) fed poultry layer waste diets in aquaria. J. Appl. Aquaculture, 12, 99-106. 
Obasa, S. O., Alegbeleye, W. O. and Amole, J. B. (2009). Dried poultry manure meal as a substitute for soybean meal in the diets of African catfish (Clarias gariepinus) (Burchell 1822) advanced fry. Turkish J. Fisheries Aquatic Sci., 9, 121-124.

Otubusin, S.O. (1990). Length weight relationship of supplementarily-fed milk fish Chanos chanos (Forskal) in brackish water ponds in the Philippines. J. Aqua. Trop., 5, 31-34.

Pathak, S. C. (1975). Length-weight relationship, condition factor and food study of Labeo calbasu (Ham.) from Loni reservoir (M.P). J. Inl. Fish. Soc. India, 7, 58-64.

Pathani, S. S. and Das, S. M. (1980). A note on length weight relationship and seasonal condition factor of mahseer Tor tor and Tor putitora (Ham.). J. Inl. Fish. Soc. India, 12,140-143.

Saha, A. K. and Ray, A. K. (1998). Incorporation of animal by-products in carp diets: evaluation of poultry litter and goat blood meal as dietary protein sources for rohu (Labeo rohita) fingerlings. J. Aqua.Trop., 13, 277-284.

Sarkar, S. K., Ganguli, S., Basu, T. K. and Medda, C. (1998). Length-relationship and relative condition factors during the early period of development of Cirrihinus mrigala (Hamilton) spawned in bundh and a hatchery, reared in experimental hoopnets. J. Aqua. Trop., 13, 95-106.

Sharma, S.C., Bali, R. K. and Katoch, B. S. (1987). Biological evaluation of some organic feeds in common carp (Cyprinus carpio var. communis). Matysa, 12-13,165-168.

Shendge, A. N. (2005). Length-weight relationship and relative condition factors in Oreochromis mossambicus (Peters) of Bhima river. J. Ind. Fish. Assoc., 32, 135-139.

Youssuf, A. R. and Pandit, A. K. (1989). Study of the ponderal index of endemic food fish of Kashmir, Schizothoraichthys niger (Heckel). J. Aqua. Trop., 4, 56-63. 